\title{
アルミニウム熔滴の水中における凝固過程と アルミニウム粒の製造法*
}

\author{
大日方一司 ${ }^{* *}$ 粟原健助“* 竹內 庸** 川西六郎**
}

Ichiji Obinata, Kensuke Kurihara, Yô Takeuchi and Rokurô Kawanishi : Some Observations on Solidification of Molten Aluminium Droplets in Water, Introducing a Method of Producing Spherical Granules of Aluminium. Dropping molten aluminium droplets weighing about 2 grams into water heated at various temperatures, the process of their solidification has been observed through peeping window set in the side of water tank. The results of observations may be summarized as follows: The shape of the solidified granules depends chiefly on the temperature of water rather than the distanceof falling to the surface of water or the temperature of molten aluminium : If the temperature of water lies between $10^{\circ}$ to $30^{\circ}$, the granules obtained showed always a irregular flat form. When the temperature of water was raised to $40 \sim$ $60^{\circ}$, the major drops solidify in a hollow spherical form; while, above $60^{\circ}$, keeping the drops in their molten state for a few meters of free sinking in the water, they solidify at last in a compact tad-pole form. From the above observations the present writers have devised a method of obtaining spherical granules of aluminium : The method consists essentially in rotating the molten aluminium droplets, by means of guide plates set in the water tank, during their sinking in the water heated at above $60^{\circ}$.

(Received November 20, 1956)

\section{I. 緒言}

主として特殊鋼造塊の場合に，1 $0 \mathrm{~g}$ 程度の球状に近い アルミニゥム粒を投入して脱酸する方法が行われている. この種アルミニウム精の製造法としては，連続した所要形 状の金型に鋳込む方法, 予め所要直径の細線としてこれを 切断成形する方法，アルミニウム熔滴を水面に設けた特殊 な装置によつて球状化し，水中で凝固させる方法(1)などが ある。

また低熔融金属の熔滴を水中に滴下させた場合に起る諸 現象，特に得られる金属粒の形状に関する考察については 長烟 ${ }^{(2)}$ ，真島(3)らの報告があるが，水中滴下だけで球状粒。

** 東北大学金属材料研究所

* 1955 年 4 月本会東京大会に発表

（1）例光ば特許公報 昭 28-6609：金属球の製造方法;昭 31-1110：粒状アルミニウム製造法.

(2) 長畑, 応用物理, 18(1949), 207.

(3) 真島, 応用物理, 21(1951), 57.
を得ることは困難である.

著者らはアルミニウム熔滴を水中㴼下させて, 直径 $10 \mathrm{~mm}$ (重量約 $2 \mathrm{~g}$ ) 程度の球状アルミニウム粒を得よ5 として，種々なる実験を行つた.すなわちまずアルミニウ ム熔滴を種々なる条件の下で水中に滴下させた場合, ぞの ような凝固過程をたどるかを観察し，これを基礎にして球 状化に適する条件を見出し, 比較的簡単に大粒の球状アル ミニウム粒を得る方法を考案した.

\section{II. 水中におけるアルミニウム熔滴の凝固過程}

\section{1. 実験方法}

Fig. 1 は実験装置の縦断面図を示したものである. (A) 断面長方形の水槽で一側面(Gをガラス張りにした。 (Bは 4 番黒鉛ルッボで, 底部に円形の穴因をうがち, 予め鋼製の ストッパー(C)で封鎻して打く.この黒鉛ルッボは約 $400^{\circ} に$ 予熱し, 実験の直前に水面上一定距離に設けた支持台(Dの 上に設置し得るようにした. この場合黒鉛ルッボ内のアル 


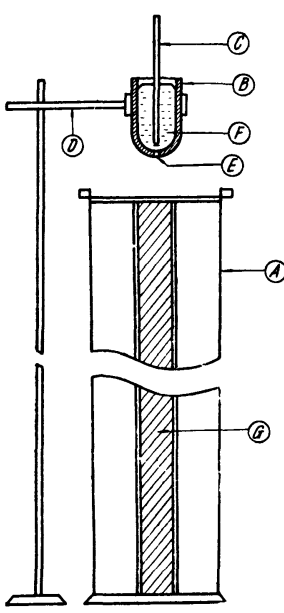

ミニゥム熔湯のヘッド，ルツ ボ底部穴の直径和よび底部穴 と水面までの空中落下距離法 それぞれ $60 \mathrm{~mm}, 4 \mathrm{~mm}$ 捈 よび $150 \mathrm{~mm}$ とした.これら の数值はアルミニウム熔湯が 底部穴より流出し， $2 \mathrm{~g}$ 程度

(A): Flush tank.

(B): Graphite crucible

(C): Stopper

(D): Supporter of crucible

(E): Flow hole

(E): Molten aluminium

G): Peep glass

Fig. 1 General arrangement of the apparatus.

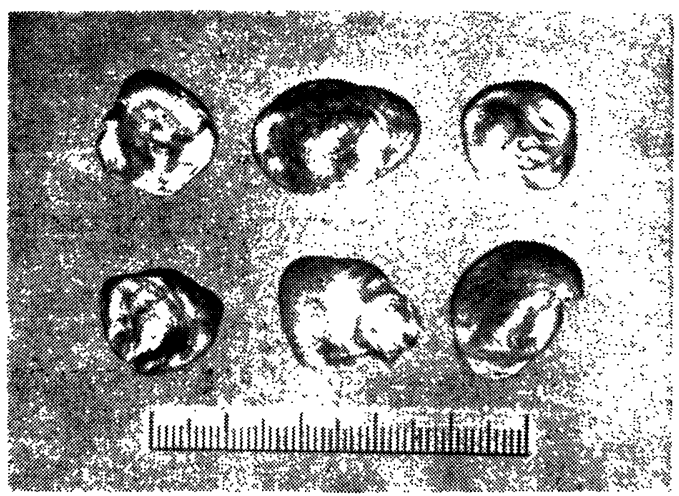

(a)
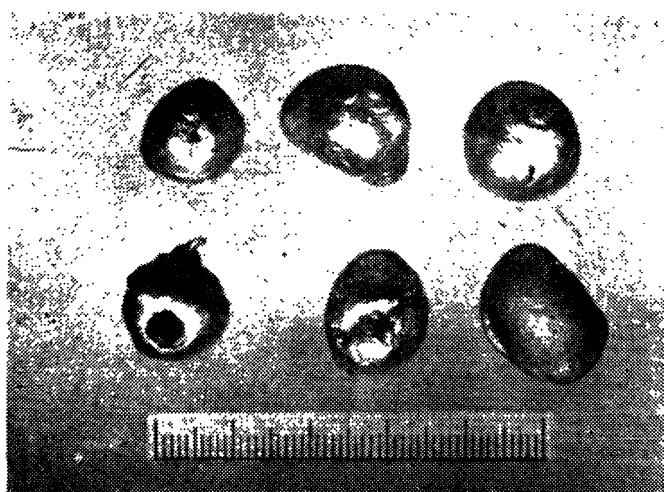

(c)

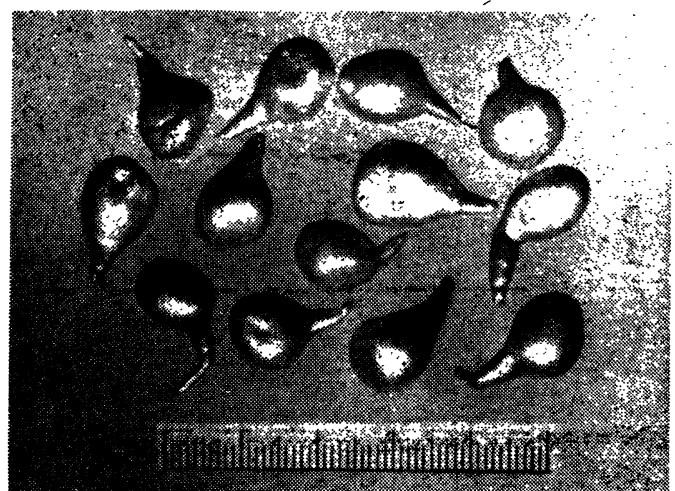

(e)
のほら゙球状に近い熔滴として, 水中に落下するように, 大 気中で行つた予備実験の結果から得られた斥のである.

使用したアルミニウム地金は純度 $99.5 \%$ のので, 予 め熔解炬で適当量を熔解し, 実験の直前に黒鉛ルツボに移 し，一定量にしてストッパーを取除き，アルミニウム熔湯 を㵜下した．この場合のアルミニウムの滴下温度は 700〜 $720^{\circ}$ であつた。

以上の諸条件の下で水温を常温より $90^{\circ}$ 附近まで順次変 化させて，アルミニウム熔滴が水中に特いてどんな凝固過 程をとるかを実験した。

\section{2. 実験 結果}

(1) アルミニウム熔湯を常温〜30 ${ }^{\circ}$ 辺までの水中 に滴下した場合

アルミニウム熔湯を $10^{\circ}$ の水中に滴下せしめると，アル

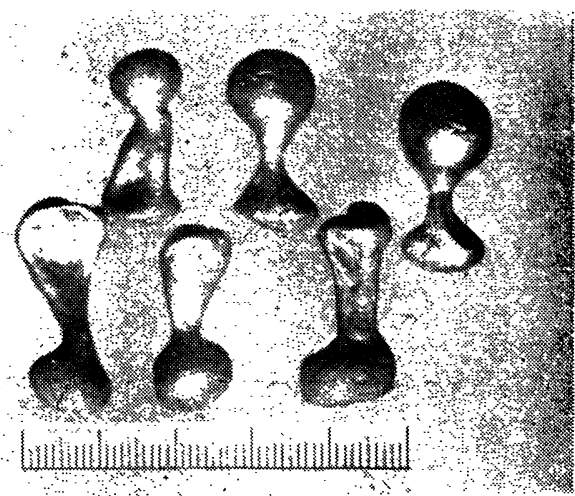

(b)

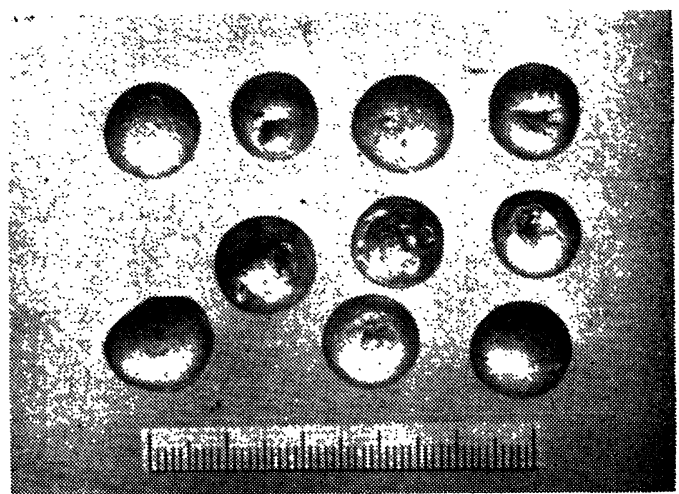

(d)

Photo. 1 Forms of aluminium granules solidified in water heated at various temperatures. Temperature of water
(a) $10^{\circ}$
(b) $30^{\circ}$
(c) $40 \sim 50^{\circ}$
(d) $50 \sim 60^{\circ}$
(e) $80^{\circ}$

ミニウム熔滴は水面に衝突するや直ちに扁平となり，急速 な冷却をらけて，そのま〉の形状を保持し，Photo１（a) に示すように不規則な貝殸状に凝固する.

$30^{\circ}$ 附近の水中に滴下せしめると，Photo. 1 (b) に示す よろなキノコ状のアルミニウム粒が得られる. このキノュ 状アルミニウム粒は水面に衝突して扁平になつた熔滴の中 
央部が重れ下つて生ずるもので，水中での初期にすでにこ の形状を呈し，その後変形することなくそのま入凝固し終 る.この種のアルミニウム粒は扁平状のものとまじつて得 られ，いずれも金属光沢を失つて灰白色を呈している.

(2) 40〜60の温水中に滴下した場合

同じ条件の下で水温を $40 \sim 60^{\circ}$ まで変光ていくと，水面 上に落下するアルミニウム熔滴の形状は比較的原形をとど め, 温水中で若干の復元運動を行いつ〉凝固する.この場 合は Photo. 1 (c)，(d) に示すような比較的球状に近いア ルミニウム粒が得られるけれぞも, 内部空洞のものが多い.

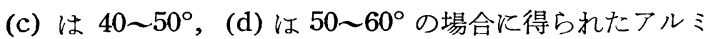
ニウム粒である.

従つてこの種アルミニウム粒は一旦水中に落下しても空 洞による浮力のため浮上するもの，中間で停帯するもの， 再び水を含んで落下するものなどその運動は極めて不規則 である.Photo.3 (b) にはこの種空洞球の断面を示した.

\section{(3) $70^{\circ}$ 以上の温水中に滴下した場合}

水温が $70^{\circ}$ 以上の場合には，アルミニウム熔滴の熔融状 態は温水中でも比較的長時間にわたつて保たれる．従つて 温水中を落下していく熔滴の復元運動も活潑となり, 前述 のような空洞のアルミニウム粒とならない.

しかしながら，アルミニウム熔滴自身の自重と熔滴に沿 5水の相対流によつて, 落下進行方向の背後に尾を発生し そのま〉の形で凝固する。すすなわち物玉构子型となる. Photo. 1 (e) は水温 $80^{\circ}$ の場合に得られた牤玉杓子型のア ルミニウム粒である.な特その形状，大きさはかなり揃つ て均一なものとなり，表面は金属光沢を保つている.

Photo. 3 (a) はこの種球状アルミニウム粒の断面のマクロ 組織で, 内部は充実し，乙かもその組織は比較的均一で柱 状晶などの存在はみられない。

\section{(4) アルミニウム熔滴の水中における凝固速度}

水温の上昇と共にアルミニウム熔滴の水中に扣汓る凝固 時間は当然大となり，従つて凝固し終るまでの水中落下距 離もまた増大する．両者の正確な測定は困難であつたが，

Fig. 1 の装置を用い@のガラス空を通じて観察した結果で は，ほぼ Table 1 に示した程度の数值が得られる。

すなわち水温が 10 ～30 の場合はアルミニウム熔滴はほ ડ゙ $1 \mathrm{sec}$ 以内て凝固し終り，その水中深度は 1 - $1.5 \mathrm{~m}$ 程度

Table 1 Results of observations during the solidification of aluminium droplets in wat $\in \mathbf{r}$ heated at various temperatures.

\begin{tabular}{|c|c|c|c|c|}
\hline \multirow{2}{*}{$\begin{array}{l}\text { Tempera- } \\
\text { ture of } \\
\text { water }\left({ }^{\circ} \mathrm{C}\right)\end{array}$} & \multicolumn{2}{|c|}{ Granules obtained } & \multicolumn{2}{|c|}{$\begin{array}{l}\text { Time \& distance } \\
\text { before solidificati- } \\
\text { on in the flush tank }\end{array}$} \\
\hline & Form* & Colour & $\begin{array}{l}\text { Time } \\
(\mathrm{sec})\end{array}$ & $\begin{array}{l}\text { Distance } \\
(\mathrm{m})\end{array}$ \\
\hline $\begin{array}{l}10 \\
30 \\
40 \\
50\end{array}$ & $\begin{array}{l}\text { Mainly (a) } \\
\text { (a) \& (b) } \\
\text { (b) \& (c) } \\
\text { Mainly (d) }\end{array}$ & $\begin{array}{l}\text { Gre } \\
\text { Gre } \\
\text { Gre } \\
\text { Gre }\end{array}$ & $\begin{array}{l}<1 \\
\sim 1 \\
\sim 1.5 \\
\sim 2.0\end{array}$ & $\begin{array}{l}\sim \sim 1 \\
1 \sim 1 . \\
5 \sim 2 \\
2 \sim 2 .\end{array}$ \\
\hline 80 & Mainly (e) & $\begin{array}{l}\text { Bright metal- } \\
\text { lic lustre }\end{array}$ & $\sim 2.5$ & $3 \sim 1$ \\
\hline
\end{tabular}

* Actual form of granules is shown in Photo. 1.
である．水温が $80^{\circ}$ 前後となると, 凝固䅂了までに $2.5 \mathrm{sec}$ 程度を要し, 水中落下距離は 3〜4 $\mathrm{m}$ に達するから, 水槽 は充分深くなければならない。

\section{III. 球状アルミニウム粒を得る方法}

既述の如く，括玉杓子型の形状はアルミニウム熔滴が温 水中に落下した初期の熔融状態に扣いて出現することを確 認したので, 球状の粒を得るためには熔融状態にあるアル ミニウム熔滴の尾の発生防止，または除去法を講ずればよ いことが判つた．そこで温水中に落下した初期のアルミニ ウム熔滴を温水中に設䚺た傾斜金属板，または適当材料の 平滑板上を転落せしめたのち，一定の水中自由落下を行わ しめ, 熔滴の形状に復元性を与え, 再び傾斜平滑板上を転

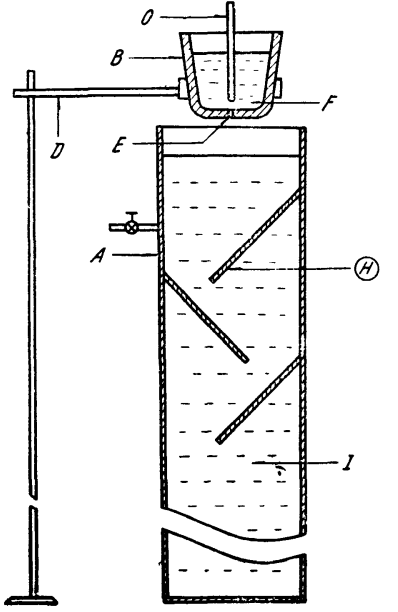

B: Graphite crucible

C: Stopper D: Supporter of crucible. E: Flow hole

F : Molten aluminium

(ii): Guide plate. 1: Hot water

Fig. 2 General arrangement of the apparatus devised in order to obtain spherical granules of aluminium.
A: Flush tank
落させて一定距離の水 中を自由落下させこ の過程を繰返して容易 に球状アルミニウム 粒を得ることができ た(4).

実験装置としては Fig.2に示すように， 温水旉内に $60^{\circ}$ の傾斜 角をもつた指導板 (1) $(0.5 \mathrm{~mm}$ 程度の銅板) を交西に数枚水面下適 当距離を扣いて設置 し，最終指導板と水面 との距離を約 $1 \mathrm{~m}$ にし た.Photo. 2 は水温 $80 \sim 90^{\circ}$ で金属指導板 を4枚交互に設置した 場合得られた球状アル ミニウム粒である.

この方法によつて得

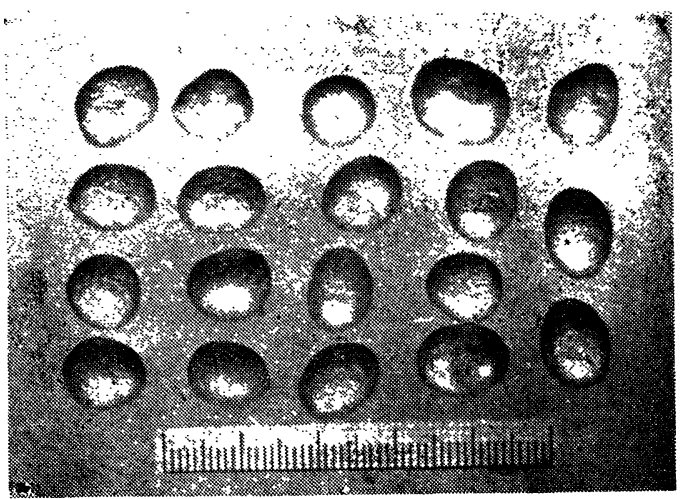

Photo. 2 Spherical granules of aluminium obtained by the method devised by the present writers.

Temperature of water: $80 \sim 90^{\circ}$. 
られた球状アルミニウム粒は重量 $1.8 \sim 2.4 \mathrm{~g}$, 直径 9 〜2 $\mathrm{mm}$ 程度のもので, 球状粒の步溜りは約 $80 \%$ である.

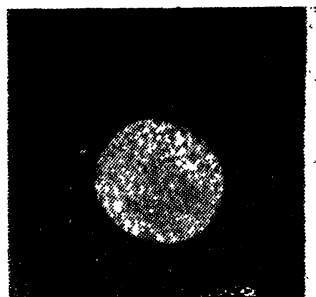

(a)

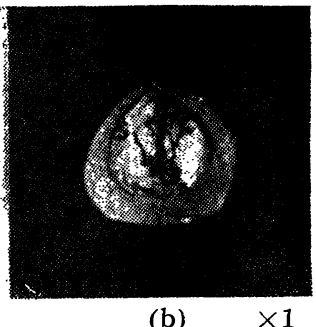

(b)
Corresponding to Photo. Corresponding to Photo.

1 (e). 1 (c).

Photo. 3 Macro-structures of the cross-section of aluminium droplets, etched with aqua reagia.

\section{IV. 考察}

アルミニウムの熔滴は水温の上昇するに従つて不規則な 貝殼状のもの, 内部空洞のもの, 和玉杓子型のものなどに 凝固することは前述の通りである. これらの形状の変化は 熔融アルミニウムの比重, 此熱, 潜熱, 表面張力, 熱伝導 などおよび水の表面張力とその冷却能によつて支配される わけであるが，比較的低温の水中に特ける場合には，水の 表面張力とその急速な冷却能が著しく影響することが判 る.

$50^{\circ}$ 前後の水温になると, 内部空洞のアルミニウム粒が 得られる. この種のアルミニウム粒は $30^{\circ}$ 附近より生じ始 め, その初期は不規則な形状のものであるが, 水温の上昇 と共に次第に円味を特びて球状化し，50６0年ではその発 生率は $60 \%$ 程度になり, 真円に近いるのとなる. それ以 上の温度では, この現象恮く消隇し, 扔玉构子型のソリ ッドアルミニウム粒に変る.

内部空洞のアルミニウム粒が得られる理由としては, 水 の泠却速度が比較的大きいために熔湯の外部が比較的早期 に凝固して殼を生ずるためと考えられる. 内部の熔融アル ミニウムは凝固に際し, ガスを発生するために, そのガス 圧により外殼が塑性的に变化して球状化するものと思われ
る.このガス圧がさらに大となれば殸を破る場合もあり得 るわけで, Photo. 1 (c), Photo. 3 (b) に示されているよ5 な破裂孔を有する内部空洞の球状粒を生ずることつなる・

水温が $60^{\circ}$ を越すと内部空洞粒の発生が減少するが, こ のことは水の冷却能が減少するためであろう．著者の一人

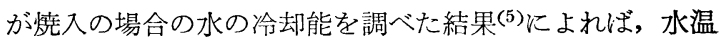
$60^{\circ}$ 附近を境にして, 水の冷却能は不連続的に変化し, 冷 却能力は著しく減少することが知られている. 水の泠却能 力の減少により, アルミニゥム熔滴は水中に和いても比較 的長時間熔融状態に保たれるため, 熔滴内の温度分布も比 較的均一となり, ガス放出も容易に行われる結果, 内部空 洞粒の発生は阻止されるものと思われる.

\section{V. 結 論}

アルミニウム熔滴の水中に物ける凝固過程に関する実験 を行つて球状アルミニウム粒を得る方法を考案した. 実験 の結果を要約すると

(1) アルミニウム熔滴を常温〜30 $30^{\circ}$ 辺までの水中に滴下 するときは，いずれも扁平不規則な貝殼状，またはキノュ 状に凝固し，金属光沢を失つて灰白色を呈するものが得ら れる.

(2) $50^{\circ}$ 前後の水温の場合には, 球状に近いアルミニウ ム粒が得られるが，内部空洞のものが多い。この種アルミ ニウム粒は $30^{\circ}$ 附近より発生し始め, $70^{\circ}$ 以上になると全 く消滅する.この現象は水の冷却特異性によるものであろ 5 .

(3) $70^{\circ}$ 以上の水温のときは，和玉杓子型の単一形状の ものとなり, 形状の大きさも揃つて均一性を特びたものが 得られ，表面は金属光沢を有し美肌を是する.

(4) 球状アルミニウム粒は熔融アルミニウム滴を $70^{\circ}$ 以 上の温水中に滴下し, 温水中に設けた指導板上の廻転と水 中自由落下とを繰返すことにより容易に得られる.

終りにこの研究の遂行には軽金属奖学会よりの援助が与 觉られたことを附記して謝意を表する.

（5）大日方，金属の研究，7(1930), 161 . 